\title{
Correction to: ISCEV Standard for clinical electro-oculography (2017 update)
}

\author{
Paul A. Constable • Michael Bach • Laura J. Frishman • Brett G. Jeffrey • \\ Anthony G. Robson - for the International Society for Clinical Electrophysiology of Vision
}

Published online: 14 March 2018

(C) The Author(s) 2018

\section{Correction to: Doc Ophthalmol (2017) 134:155 https://doi.org/10.1007/s10633-017-9580-3}

The article "ISCEV Standard for clinical electrooculography (2017 update)", written by Paul A. Constable, Michael Bach, Laura J. Frishman, Brett G. Jeffrey, Anthony G. Robson and for the International Society for Clinical Electrophysiology of Vision, was originally published Online First without open access. After publication in volume 134, issue 1, pp. 1-9 the authors decided to opt for Open Choice and to make the article an open access publication. Therefore, the copyright of the article has been changed to (c) The Author(s) 2017 and the article is forthwith distributed under the terms of the Creative Commons Attribution 4.0 International License (http://creativecommons.org/licenses/by/4.0/), which

The original article can be found online at https:// doi.org/10.1007/s10633-017-9580-3.

\section{P. A. Constable $(\bowtie)$}

Discipline of Optometry and Vision Science, Flinders

University, Adelaide, Australia

e-mail: paul.constable@ flinders.edu.au

\section{Bach}

Department of Ophthalmology, University Medical

Center Freiburg, Freiburg, Germany

L. J. Frishman

College of Optometry, University of Houston, Houston,

TX, USA permits use, duplication, adaptation, distribution and reproduction in any medium or format, as long as you give appropriate credit to the original author(s) and the source, provide a link to the Creative Commons license, and indicate if changes were made.

The axis label in figure 5 should read $25 \mathrm{~s} /$ division and not $25 \mathrm{~ms} /$ division.

An erratum (https://doi.org/10.1007/s10633-0179580-3) was published to make the article open access. Unfortunately, the copyright of the article incorrectly remained (C) Springer-Verlag Berlin Heidelberg 2017. Therefore, the copyright of the article has been correctly changed to (c) The Author(s) 2018.

Open Access This article is distributed under the terms of the Creative Commons Attribution 4.0 International License (http:// creativecommons.org/licenses/by/4.0/), which permits unrestricted use, distribution, and reproduction in any medium, provided you give appropriate credit to the original author(s) and the source, provide a link to the Creative Commons license, and indicate if changes were made.

\section{B. G. Jeffrey}

Ophthalmic Genetics and Visual Function Branch,

National Eye Institute, Bethesda, MD, USA

\author{
A. G. Robson \\ Institute of Ophthalmology, University College London, \\ London, UK
}

\author{
A. G. Robson \\ Moorfields Eye Hospital, London, UK
}

